\title{
Feminism: An Exploration of Pragmatics of Women Lives in Namita Gokhale's Works
}

\author{
P. Priyadharshini \\ Department of English, Kalasalingam Academy of Research and Education, Krishnankoil-626126, Tamil Nadu, India
}

S. Mohan

Department of English, Kalasalingam Academy of Research and Education, Krishnankoil-626126, Tamil Nadu, India

J. Sangeetha

Department of English, Kalasalingam Academy of Research and Education, Krishnankoil-626126, Tamil Nadu, India

R. Kannan

Department of English, Hindustan Institute of Technology and Science, Chennai-603103, Tamil, Nadu, India

\begin{abstract}
Feminism is a women's movement fighting for equal rights and status. The purpose of this study concentrates on the reflection of feminism in Namita Gokhale's selected works The Book of Shadows (1999), Priya: In Incredible Indyaa (2011), and Things to Leave Behind (2016). The features of feminism strive for equal rights for both men and women, particularly the emancipation of women, fight for their rights, freedom, equal rights, and gender issues. Namita Gokhale is a famous writer, and her notable works are The Book of Shadows, Priya: In Incredible Indyaa, and Things to Leave Behind. These selected works address the issues of feminism. The major protagonists of these selected works of Namita Gokhale are Rachita, Tilottama and Priya. Each character's life reflects the issues of feminism theory. Some famous feminists are Rachel Speght, Olympe de Gouge, Mary Wollstonecraft, Judith Sargent Murray, Fredrika Bremer, Elizabeth Cady Stanton and so on. The methodology of this study focuses on the feminist theory which is compared with Namita Gokhale's selected works. In discussion, the researchers compare the survey with the other studies for deeper understanding. Future study recommendations are alienation, self-identity, psychoanalysis, self-disorder, and parental care.
\end{abstract}

Index Terms - feminism, women existence, women's rights, education, social discrimination

\section{INTRODUCTION}

Mary Dickenson correctly points out about feminism that "Men are terrified of being laughed at by women. Women are terrified of being killed by males" (Dickenson, 1996). Feminism asserts that women are equal to men. There are different types of feminism, and they are liberal feminism, marxist feminism, radical feminism, cultural feminism, Ifeminism, ego feminism and so on. This theory argues about women's rights and to live their life freely. Feminism doesn't mean fighting with men; instead, they support men for a better cause. Besides, some men's rights activists support women's lives and speak for women's rights.

In this study, the researchers selected Namita Gokhale's works The Book of Shadows, Priya: In Incredible Indyaa, and Things to Leave Behind. This study aims to analyse the features of women through theories of feminism proposed by famous feminists. Further, this study includes a review of literature, methodology, discussion, and conclusion. These sections give the uniqueness of the current study. The literature review focuses only on feminism related articles reflected in various novels. The methodology of this study focuses on the feminist theorist's view on feminism, which is then compared with Namita Gokhale's selected works. In the discussion part, the researchers will compare the results obtained in this study with the other researchers' studies. This study strengthens the comparisons and analysis with feminist theories and Namita Gokhale's selected works.

\section{REVIEW OF LITERATURE}

The literature review is more important in every study because it gives different ideas to the research. The current study focuses on feminism, so the current study focuses on the review of articles concerned with feminism.

The study of Crowe discusses Connell theory of feminism. In this study, the researcher employs Connell's ideas of feminism in two ways. They are the divisions of women in feminism and men in feminism. This research discusses man's opinions about feminism because feminism believes men are also the supporters of a woman's life (Crowe, 2011). Sulistyo's study reveals the ideas of feminism through the work The Palace of Illusions. Through the character Krishna, feminism issues are reflected in this work. The male character in this study is supported by feminist philosophy. The researcher behind this study speaks out in support of women (Sulistyo, 2021). 
Another study by Prajjal Saha's study discusses the life of women within the realms of society and family. This discussion supports "women genetically designed to be multi-skilled and multi-talented". Women are leading a successful life as a mother, sister, wife, workers, and so on. This study also discusses the different stages and various problems faced by women in their life (Saha, 2015). The study highlights the contribution of several male writers in aiding or the welfare of women in which the author, Pittman, and Reich particularly focuses on MCGorry's contribution in unveiling the value of women. His ideas support men in feministic point of view in which he says that becoming feminist is easier for men because the supporters of women's rights are called feminist. According to MCGorry views on feminism this research has discussed the male feminist's notion of feminism (Pittman and Reich, 2016).

The study of Honig's highlights the idea of feminism through the relationship between father and child. Women go through several life stages, such as sister, child, mother, wife, and so on. These women's life stages are contrasted with those of men. In this study, the researcher discusses man as father, brother, and husband (Honig, 2018). Desmawati's study of feminism analyses the novel Little Women by Louisa May Alcott. In this study, the researcher evaluates different types of feminism and analyses the reflection in Louisa May Alcott's selected novel. The selected theories for this study are Liberal feminism, Marxist feminism, Existentialist feminism, and Radical feminism. According to this study, feminism is about women eliminating all marginalised habits in society and at home (Desmawati, 2018). The study of Haiyan analyses feminism in Jane Eyre by Charlotte Bronte. Also, this research focuses on victoria age and feminism. The researcher Haiyan focuses primarily on the Victorian era because each era presents different obstacles to women's life. So in this study, the researchers only concentrates on a particular age, and Victorian age published work Jane Eyre written by Charlotte Bronte (Haiyan, 2013).

The study of Cheryl analyses the different types of feminism in the view of Alan Williamson. As a man, he discusses the theory of feminism from the female perspective in the text Almost a Girl: Male Writers and Female Identification. The researcher selected four works for this study, they are The Joy Luck Club, She's Come Undone, Une Si Longue Lettre (So Long a Letter), and La Femme du Mari Inconnu (The Wife of the Unknown Husband). The selected works are compared with each other to investigate the different problems of women. In the result, the researcher confirms that men can write from the female viewpoint in a way that is perfect, respectful, and progressive (Cheryl, 2008).

The study of Jaha and Darmastuti discusses gender discrimination and the perspectives of feminism. Also, this study discusses marginality, subordination, stereotype, violence, and double burden. The feminism theory mainly focuses on the three women characters such as Dorothy Voughan, Marry Jackson, and Katherine Johnson (Jaha and Darmastuti, 2018).

The study of Nur Azizah and Nurl Fitri abbreviates liberal feminism in the movie 'The Post' through the protagonist, Katherine Graham. The authors have adopted a qualitative and descriptive method in this study and utilised Marilley's theory. The authors categorised three types of liberal feminism. They are feminism of equal rights, feminism fear and feminism of personal development (Azizah and Fitri, 2019).

Regardless of the fact that there are several theories regarding feminism, only a few research utilising novels have been done. The authors of this study can deduce from the preceding discussion that no research has been conducted using Namita Gokhale's work. This inspires the researchers to take this issue in this study to discuss feminist point of view in Namita Gokhale's selected works The Book of Shadows (1999), Priya: In Incredible Indyaa (2011) and Things to Leave Behind (2016).

\section{METHODOLOGY}

The methodology part gives valid and reasonable consequences for the study. To explore this idea in this research, the researchers selected the feminist theory. The researchers in this section will compare feminism ideas to selected works by Namita Gokhale's selected works such as The Book of Shadows (1999), Priya: In Incredible Indyaa (2011) and Things to Leave Behind (2016).

Shahrzad tells about feminism that "Women's emancipation is the goal of feminism. The ideals of Marxism also advocate for women's emancipation. Both are advocating for emancipation within the capitalist political and legal system" (Shahrzad, 2015). This point of view reflects on Namita Gokhale's selected works. In Things to Leave Behind, Namita Gokhale introduces the character Tilottama, who seeks freedom from her family. Since Tilottama struggled to receive an education from her mother-in-law. Tilottama's child was likewise turned down by her family. Namita Gokhale expresses this situation that, "Nain Chand fell love with his child from the moment she was born. Her mother found her odd-looking. I can't understand it,' she would say to her family. 'Why is her hair such a strange colour?'” (Gokhale, 2016).

Further, Shahrzad tells that, "The growth of women as a new social and political power, as well as their commitment to change the tangible reality of obsessive and unfair gender relations, has resulted in feminist consciousness. This consciousness has transformed gender relations via fights for 'rights' through the practice of women's movements across the world, but it has failed to deconstruct the hierarchy of gender relations" (Shahrzad, 2015). Likewise, the protagonist Rachita in the novel, The Book of Shadows, endures many hardships in society, as her acid attacked face ruined her physical appearance and life. She fights with her life for her freedom and rights. She tells about her hatred towards the society that, "I was getting tired of human talk, it used too many wards, and their hysteria sickened me. I reverted to another dimension, a dimension of Peace, such immense empty solitude that sometimes it is difficult to 
penetrate" (Gokhale, 1999). Also, Rachita tells about freedom that, "Every man has the right to fulfil his own will without being afraid that is may interfere with that of others" (Gokhale, 1999).

Shahrzad tells his own experience in his book Feminism and Marxism that "My mother came from a middle-class household, and my maternal grandfather was literate, encouraging his four granddaughters to pursue higher education and become involved in the community. He encouraged women to be self-sufficient and leave their spouses as soon as they became burdensome. My mother was free to pick my father, her future spouse, whom she met at her volleyball coach's house" (Shahrzad, 2015). This incident of Shahrzad is also reflected in Namita Gokhale's work Priya: In Incredible Indiyaa. In this work protagonist, Priya teaches her children to be free and independent to choose their life on their own. Priya also gave her kids the choice of selecting their soul mate. Priya's husband Suresh, on the other hand, is the complete antithesis of her in every situation (Priyadharshini and et al., 2021) Priya, on the other hand, is in charge of her husband and children. She also recognises that one of everyone's rights in life is the ability to choose. As a result, Priya's child's life was unrestricted (Gokhale, 2011).

Another feminist, Steinem tells his view on feminism that, "Feminists believe in the equal rights and full equality of men and women" (Steinem, 2015). This reflects through Namita Gokhale's work Things to Leave Behind. The author supports the men and women in her novel. Namita Gokhale understands the situation of women and men in both private and public life. She supports men and women that Namita Gokhale expresses through the Tilottama's husband. That he tells, "he lost his temper. 'You are jealous and small minded people!' he exclaimed. 'Besides, Tillie does not know any English and Englishmen either!" (Gokhale, 2016). Based on Tilottama's words, the researchers of this study conclude that Tilottama's husband is a solid supporter of his wife in all scenarios.

Wollstonecraft explicates that "I adore man as a friend; but his sceptre, real or fictitious, does not extend to me unless the reason of the person requires my devotion; and even then, it is to reason, not to man, that I submit" (Wollstonecraft, 2013). This reflects in Namita Gokhale's Priya: In Incredible Indiyaa the protagonist Priya. She marries the richest person but Priya belongs to the middle class family. Priya's husband supports his wife in every place and every situation. She had the rights to choose her own attire and to give gifts to others. She also had the right to lead her children. Priya tells that, "I actually pinch myself sometimes to check that it's real, this house and me in it" (Gokhale, 2011).

Priya is the main and important character in the novel. She is the wife of Suresh Kowsal. Before her marriage, she lives in Mumbai and after her marriage she resides in Delhi. Mumbai is more traditional city when compared to Delhi. She has twin son names Luv and Kush. She allows her son to lead their life as per their wish and also allows them to choose their partners as they wish. But, her husband is opposite to her. He believes that modern women are not suitable for the family life. At the end, Priya's husband changes his character and he allows Priya to do as she likes. Suresh realises that women are having their free life, as he tells that, "A husband, a family, respectability. She can't ever steal these from me. Can she?!" (Gokhale, 2011). Margret Atwood tells that "Men are frightened of being laughed at by women. Women are frightened of being killed by males" (Atwood, 1985). So both genders are abrading of other gender. This happens in Namita Gokhale's Novel Things to Leave Behind. Tilottama's fear and reluctance prevented her from expression her thoughts. And her husband is also in a similar situation. This shows that it is an obstacle for both of them to share their evolutions. In Tilottama's life the elders took major role. So, Tilottama and her husband lived under the control of elders in their family. The uses of words are the very important thing in every human life. Because the spoken word will create a person and the same words have the power to destroy a person's life. The power of words are cannot be comprehended by everyone. Even Rachita, the protagonist of Namita Gokhale novel, didn't use the harsh words through her fiancé's sister. On the other side, her fiancé's sister does not say anything and instead throws acid in her face. As a result of such occurrence, Rachita's life was imperilled.

Roman Payne tells about women life, "She was free in her wildness. She was a wanderer, a drop of free water. She belonged to no man and to no city" (Payne, 2013). This represent for all people in the world. Because each having their own life to live their life. This idea reflects in Namita Gokhale's work. Tilottama, the protagonist in the novel Things to Leave Behind has the reflection of idea through her lifestyle. That she did not expect anything from husband or motherin-law. But she chooses her life as she likes.

Vikki Bell tells about the alienation in feminism that, "One may say that politics starts with how the problems of the unethical are dealt with. If this is the case, the ethical challenge inside feminism can be reframed. Instead of being a check on liberty and politics, morality has become a check on both." (Bell, 2001). This point of view reflects in Rachita's life that she tells, "I do not think I was involves in any way, at least not voluntarily. Sometimes our impulses achieve a life of their own". Further, Rachita tells that, "Human minds are intrinsically weak unless they are kept in careful check by the physical counter-motion of their bodies. Lazy to the bone, rotten to the core, far from the home... (Gokhale, 1999).

\section{DISCUSSION}

In the discussion part, the researchers of this study, compares this study with result of other studies. To compare, the researchers selected the feminism based research. The present study is compared with other studies for a deeper understanding of the concepts of feminism. 
Gardiner's study examines discriminations in working place. Also, this study focuses on the features of discrimination that reflects in the women's life. But in this current world, there are many women working with men. They help each other without any discrimination. This story focuses on the equal treatment in working place. In the modern time, women are also doing their work equal to men. Both genders are helping each other in most of the places (Gardiner, 2005). This idea reflects in Namita Gokhale's text Priya: In Incredible Indiyaa. For example, the Protagonist Priya in the work Priya: In Incredible Indyaa lives her life equal with his husband. She did not expect anything from her husband and she fulfils her needs on her own. The following quotation shows the equality between Priya and her husband. 'She will be an asset to our family...' Suresh said fondly, 'just as you are!' 'Oh, me...I'm just a housewife!' I protested. But it feels good to be appreciated" (Gokhale, 2011). This shows the bond between Priya and her husband Suresh.

Further, the study of Sulistyo discovers theory of feminism in The Palace of Illusions. Here the study describes the men's role in women's life. The analysis of this study discusses male point of view about women. The people are having the different point of view of others. This study discusses different life style of women and their problems (Sulistyo, 2021). This point of view reflects in Namita Gokhale's Priya: In Incredible Indiyaa. Priya's husband Suresh understands the difficulties of handling the family as a mother, wife and so on (Gokhale, 2011).

The study of Crowe discusses Connell theory of feminism. In this study, the researcher used Connell's ideas of feminism that reflects in two ways in his study. The divisions are women in feminism and men in feminism. This research is discussed man's opinion about feminism because feminism believes men are also the supporters of a woman's life (Crowe, 2011). This point of view reflects in the work The Book of Shadows that Rachita tells“... to be ourselves we must remain in control of our scripts. We must make and remake ourselves; we must possess and repossess our world, cast and recast our lot in every precious moment. Above all, we must know what to hold on to, what to discard, in this radical flux which is life" (Gokhale, 1999). This demonstrates that Rachita lives her life how she wishes.

There are many writers and researchers discussing about the women and their life. But there are still many problems are faced by women. In Namita Gokhale's The Book of Shadows Rachita tells "I have come to the hills to heal, to hide, to forget. To forgive, to be forgiven. My friends all restricted my decision. My sister even insisted in accompany me here, but I knew that I needed solitude and soliloquy to come to terms with what had happened" (Gokhale, 1999). These lines explain the condition of Rachita's life as she struggles a lot to come out of her personal problems. Rachita's life, also explores the sufferings of every women condition.

Rachita's increasing loneliness makes to analysis her life with philosophic and traditional way. She learns that the people have to know about every precious time of the life. The life has changes in every movement and she realises what she should take from life and what she should leave behind for her own good. For, her being alone makes her to be strong and she strengthened her mind. Rachita believed herself rather than believing her relatives and society. She tells that, "I have learnt from bitter experience that is no solace or relief in philosophising - it only exacerbates the wounds of my fractured experience". Further she explores that, "It is terrible to be suspended I time and space, without a body, without a context, ignorant of the reasons and circumstances that have led to this strange exile, this cruel isolation" (Gokhale, 1999).

In Pittman and Reich's study, the authors discuss the point of view of male feminism. There are many research carried out with the themes of male contribution towards feminism. MCGorry's ideas are used in this research to bring the value of women. MCGorry's ideas support men in a feministic point of view that he says becoming feminist is easier for men because the supporters of women's rights are called feminist. According to the MCGorry view of feminism, this research has discussed the male feminist's system of feminism (Pittman and Reich 2016). This point of view is also reflecting in Namita Gokhale's work The Book of Shadows. One of the main characters tells that, "Every man has the right to do what he wants without fear of others interfering with it..." (Gokhale, 1999).

\section{CONCLUSION}

The ideas of feminism theory are focussed on the current study. This study investigates feminism theory in Namita Gokhale's Priya: In Incridible Indyaa, The Book of Shadows, and Things to Leave Behind. To analyse the feminism theory, this study selected some important theorists ideas of feminism. The comparisons with results of other studies give the uniqueness and novelty of the current study. Finally, this study's discussion proves that feminist ideas are reflected in Namita Gokhale's select works (Priyadharshini et al., 2021). Future researchers can get new ideas from the limitation of the current study. Future analyses can be carried out in the concepts of self-identity, self-disorder, alienation, psychoanalysis, feminism, and so on.

\section{REFERENCES}

[1] Azizah, N., \& Fitri, N. (2020). The Representation of Liberal Feminism through the Main Character in "The Post" Movie. JELT: Journal of English Language Teaching, 3(2), 84-94.

[2] Bell, V. (2001). On ethics and feminism: Reflecting on Levinas' ethics of non-(in) difference. Feminist Theory, 2(2), 159-171. DOI: $10.1177 / 146470010100200203$

[3] Craciun, A. (Ed.). (2013). Mary Wollstonecraft's A Vindication of the Rights of Woman: A Sourcebook. Routledge. 
[4] Crowe, J. (2011). Men and feminism: some challenges and a partial response. Social Alternatives, 30(1), 49-53.

[5] Desmawati, E. (2020). Analysis of feminism in the novel of little women by Louisa May Alcott. Journal of Language and Literature, 6(2), 91-96. DOI: 10.35760/j11.2018.v6i2.2487

[6] Dickenson, M. (1996). A woman's worst nightmare. No safe place: Violence against women.

[7] Gao, H. (2013). Reflection on Feminism in Jane Eyre. Theory \& Practice in Language Studies, 3(6), 926-931. DOI:10.4304/tpls.3.6.926-931

[8] Gardiner, J. K. (2005). Men, masculinities, and feminist theory. Handbook of Studies on Men and Masculinities, December, 35-50. DOI: 10.4135/9781452233833.n3

[9] Gokhale, N. (1999). Book of Shadows. Penguin Books India.

[10] Gokhale, N. (2011). Priya: In Incredible Indyaa. Penguin UK.

[11] Gokhale, N. (2016). Things to Leave Behind. Penguin UK.

[12] Honig, A. S. (2008). Supporting men as fathers, caregivers, and educators. Early Child Development and Care, 178(7-8), 665687. DOI: $10.1080 / 03004430802352020$

[13] Jaha, A. A., \& Darmastuti, S. M. (2018). Feminism as Reflected in Margot Lee Shetterly's Hidden Figures Novel. JELLT (Journal of English Language and Language Teaching), 2(2), 51-60. DOI: https://doi.org/10.36597/jellt.v2i2.3273

[14] Lange, C. (2008). Men and women writing women: The female perspective and feminism in US novels and African novels in French by male and female authors. UW-L Journal of Undergraduate Research, Volume 11, 1-6.

[15] Mojab, S. (Ed.). (2015). Marxism and feminism. Zed Books Ltd..

[16] Pittman, M., \& Reich, B. (2016). Social media and loneliness: Why an Instagram picture may be worth more than a thousand Twitter words. Computers in Human Behavior, 62, 155-167. DOI:doi:10.1016/j.chb.2016.03.084

[17] Prajjal, Saha. (2015). "Are women genetically designed to be multiskilled and multitalented?" Retrieved from November 24, 2021. Available at: (hrkatha.com).

[18] Priyadharshini, P. et. al., (2021). Psychological analysis of Ipseity Disturbance (ID) in Namita Gokhale's work The Book of Shadows. Journal of Language and Linguistic Studies, 17(4).

[19] Priyadharshini, P. et. al., (2021). Authenticity of liberal feminism in Namita Gokhale's texts. Linguistics and Culture Review, 5(S1), 46-59.

[20] Steinem, G. (1992). Revolution from within: A book of self-esteem, Boston: Little-Brown.

[21] Sulistyo, N. Y. (2021). The Male Feminism of Krishna in Chitra Lekha Banerjee Divakaruni's The Palace of Illusions. Jurnal Ilmiah Spectral, 7(1), 029-039. DOI: https://doi.org/10.47255/spectral.v7i1.66

P. Priyadharshini is currently pursuing her PhD in full time at Kalasalingam Academy of Research and Education, Tamil Nadu, India. Her research interests are Indian literature, women's writing in English, literary theory, in particular feminism theories, and psychological theories.

S. Mohan is a faculty of English at Kalasalingam Academy of Research and Education, Tamil Nadu, India. He has been teaching a number of courses on World Literatures and Language Teaching over the years, as well as more general courses in Communicative English, Business Communication and Soft skills. His research and publication interests include ESP, ELT, African-American Literature and Education. He has published and presented more than fifty articles in various reputed journals and conferences. He was also served as an External Examiner for PhD scholars in different universities and Associate Editor, Editorial member in various International Journal Publication at home and abroad.

J. Sangeetha was born in Madurai, India in 1996. She has completed her Post Graduate Degree from Lady Doak College, Madurai in 2019 and she is currently pursuing her PhD in full time at Kalasalingam Academy of Research and Education, Tamil Nadu, India. Her research interests include emerging trends in contemporary literature, Feminism and Indian Literature.

R. Kannan is an Associate Professor in the Department of Languages, Hindustan Institute of Technology and Science, Chennai, India. His research interests include ELT and Literature. He has published research articles in reputed national and international journals besides being actively participatin in national and international conferences. He is a certified Speaking Examiner for Business English Certificate Courses by Cambridge Assessment English, UK. Recognised research supervisor for Ph.D and an External Examiner for Ph.D. Scholars in different Universities across India. 